\title{
Study on Air Crash Compensation Based on Private International Law Development Trend
}

\author{
Pengfei Ji \\ Department of Foundation, Northeast Petroleum University at Qinhuangdao, Qinhuangdao, China \\ Email: guicaitang@163.com
}

Received 17 January 2015; accepted 8 February 2015; published 13 February 2015

Copyright (C) 2015 by author and Scientific Research Publishing Inc. This work is licensed under the Creative Commons Attribution International License (CC BY). http://creativecommons.org/licenses/by/4.0/ c) (i) Open Access

\begin{abstract}
In recent years, air crashes have occurred frequently, so the resulting compensation issues are extremely complex. Air crash compensation is mainly involved with the amount of compensation, application of law and jurisdiction, including domestic law and private international law. The provisions on it are different in different countries. How to protect the air crash victims' rights effectively is always a difficult problem in the research of scholars of all countries. In this paper, combining with the typical air crash cases, the author puts forward the problems in the private international law and gives some suggestions to further improve the legislation of private international law.
\end{abstract}

\section{Keywords}

\section{Conflict of Laws, International Treaties, Jurisdiction, Compensation for Mental Damage}

\section{Conflict of Laws and International Treaties}

Solving the dispute of the air crash is first confronted with the conflict of laws among different countries. As most of passengers in the international air crash case have different nationalities, it will inevitably produce conflict of laws to determine the applicable law of which country to settle the dispute. Therefore, to resolve the air crash dispute is required to follow the conflict rules of private international law, seeking the most favorable legal norms and international treaties to safeguard the rights of died citizens in the air crash. It is very complex to confirm the responsibility of the air crash, and the international treaties each country joined are different. Therefore, the detailed judicial cooperation can solve the problem of the confirmation of responsibility effectively [1]. 
The amount of compensation to the casualties in the air crash is not same because each country's provisions on it are different; and there are a lot of relevant international treaties and domestic laws and regulations. The domestic laws of some countries intervene, and the agreements of different countries' airlines are various. As a result, the compensation limits are different in different countries and for different air lines. Moreover, due to the different country's level of economic development and per capita income, the compensation amounts also are different to passengers. So, passengers died in the same accident, but the amounts of compensation are different, applicable to different international treaties or the relevant domestic laws. To solve the difficult problem of "equal life in different price" in the international air crash, it is extremely urgent to unify the different provisions between international treaties and domestic laws. Meanwhile, it can effectively stop the families of the victims to circumvent the law in the air crash compensation. In a word, it is suggested to unify the different provisions of the relevant international treaties and private international law, establish the international coordination mechanism and make unified and feasible provisions for the amount of compensation in the international air crash in order to solve air crash disputes.

\section{Baotou Air Crash and Its Jurisdiction}

Since 11/21 Baotou air crash occurred within the territory of China on November 21, 2004, the nature of the case was undoubtedly defined as the domestic infringement, and China had the jurisdiction over this case, and this case was supposed to be taken under the jurisdiction of Chinese courts and heard by a Chinese court, but the responsible Chinese court took so long for case filing. It was in the year of 2009, the fifth year after the occurrence of the case of Baotou air crash, when the families of victims in Baotou air crash received the notice of acceptance from Beijing Second Intermediate People's Court. The petition and prosecution families of the victims conducted had always been ignored for five years and obtained no response before Baotou air crash was accepted by Beijing Second Intermediate People's Court. Domestic court's negative attitude towards this case coupled with the intervention of American lawyer who alleged this case concerned the product liability under America's jurisdiction considering that the malfunctioning engine of the passenger aircraft which was seen attributable to the air crash was manufactured by USA General Electric Company, the American lawyer filed a lawsuit against the engine product liability in America, in consequence, the case of Baotou air crash was converted from a case of domestic infringement to a case of foreign infringement, and the conversion of the jurisdiction over this case seriously violated our national sovereignty.

In general, the determination of court's jurisdiction is the foundation to solve all international civil and commercial cases, so it comes to the proceedings and substantive facts only after the jurisdiction is determined. The determination of jurisdiction is mainly in accordance with the international treaties and domestic legislation. China has adopted a number of treaties concerning air transportation, among which, "Warsaw Convention” and "Montreal Convention" explicitly stipulate the jurisdiction [2] [3]. The law of our country stipulates that international treaties shall prevail in case of any conflict between international treaties and domestic legislation, whereby, to determine which country has the jurisdiction over Baotou air crash shall be subject to the international treaty to which our country has acceded as a matter of priority. This case was eventually accepted by an American court, and we are not discussing about whether it conforms to the provisions of treaties, but focusing on the resulting conversion of legal jurisdiction. Since the jurisdiction was transferred to American court, the applicable law changed accordingly. As per the guidelines of the Conflicts of Laws of USA, the appropriate governing law shall be American law. Under a certain condition, domestic infringement can be converted into foreign infringement by converting the nature of the case. The goal of conversion of jurisdiction over the case was achieved through converting the aviation infringement case into a foreign product liability case in this case.

The determination of court's jurisdiction is of great significance on international civil procedures. The jurisdiction issue is closely associated with the principle of national sovereignty, and concerns the complicated and intense international struggle for jurisdiction. With respect to the domestic court's inaction on the case of Baotou air crash, we shall prevent its re-occurrence in the future international civil and commercial cases and learn experience from courts in other countries on how to win the court's jurisdiction over international air crash more effectively. The conversion of jurisdiction over Baotou air crash is a result of the legal deficiencies of our country on filing an international civil and commercial case and such deficiencies include overdue case filing, narrow range of case filing, etc., the legislative design can be applied to improve Chinese courts’ jurisdiction over international air crash cases from the following aspects. 
Firstly, we should learn from the long-arm jurisdiction of the United States. Long-arm jurisdiction is an exclusive extended jurisdiction principle in the United States, and refers to the authority of a court to exercise the personal jurisdiction and to hear a case against a defendant outside the jurisdiction concerned as long as there exist "minimum contacts" between the defendant and the forum State and the mentioned right is related to such contact even though the defendant resides outside the US court's jurisdiction concerned. Although long-arm jurisdiction may deprive courts in other countries of the inherent jurisdiction over a case, its flexibility is undeniable, for example, if courts in other countries fail to accept or rule a case in due time, exercising the long-arm jurisdiction is a fast way to accept the case and settle the dispute. We should judge and discuss the long-arm jurisdiction from the perspective of fairness and substantial justice. In view of the interests of the whole humanity, the long-arm jurisdiction does better in balancing the difference between laws of different countries, and it is more conducive to the protection of the interests of victims and more adaptive to the modern life. Specific to the case of Baotou air crash, the Court of California exercised the long-arm jurisdiction to hear this case only because the malfunctioning engine was manufactured by USA General Electric Company. On the surface, US had expanded its jurisdiction, while in consideration of the interests of the whole humanity, we should learn from the flexibility of the principle.

Secondly, the "Civil Procedure Law" shall specify the doctrine of forum non conveniens. The doctrine of forum non conveniens is a doctrine whereby courts have the discretionary power to refuse to take jurisdiction over civil and commercial cases where the court is considered as an inappropriate forum regardless of its inherent jurisdiction over the case and there is more appropriate forum available to the parties. In judicial practice, the application of this doctrine has been constantly proved to be reasonable, and in the legislative process, this doctrine has been absorbed continuously. In 2005, the Supreme People’s Court issued the "Second National Foreign-related Commercial and Maritime Trial Work Meeting Minutes”, specifying the applicable conditions of the doctrine of forum non conveniens in our country. The promulgation of the "Minutes" is a milestone for clearly determining China's jurisdiction over the foreign civil and commercial cases at the acceptance stage. The doctrine is expected to make progress and develop constantly. When it comes to the case of Baotou air crash, the carrier is China Eastern Airlines, the accident occurred in China and the material evidence and witnesses are mostly in China, so it is more appropriate for Chinese court to exercise the jurisdiction, which would provide convenience for Chinese passenger victims and safeguard the interests of Chinese tourists to its largest extent and US court ultimately made a decision to suspend the trial by invoking this doctrine [4] [5].

The doctrine of forum non conveniens plays an important role in international civil procedures, effectively alleviates the conflict of jurisdiction, diminishes the "dispute” or fight for the authority of jurisdiction over international civil and commercial cases between courts in different countries and greatly promotes the cooperation between courts in different countries, which giving full play to the value of this doctrine. The doctrine of forum non conveniens can be applied to achieve the substantial justice and to effectively solve the rigidity of applicable jurisdiction rule arose by the determination of forum according to international treaties, which is favorable for the families of victims in air crash to select more appropriate forum for suing.

\section{Asiana Air Crash and Its Compensation for Mental Damage}

Following "Warsaw Convention”, “Montreal Convention” is signed to ensure the rights and interests of international aviation consumers. The Convention gives more substantive rights to international air transport consumers, and provides carrier's compensation for the loss of goods and luggage damage, and the competent court and arbitration. However, "Montreal Convention" does not give a specific compensation standard, and only gives general provisions on the highest amount that carriers need to compensate. It provides that "in relation to the transport performed by the actual carrier, the aggregate of the amounts recoverable from that carrier and the contracting carrier, and from their servants and agents acting within the scope of their employment, shall not exceed the highest amount which could be awarded against either the contracting carrier or the actual carrier under this Law, but none of the persons mentioned shall be liable for a sum in excess of the limit of liability applicable to him.”

In terms of the Asiana Airlines Air Crash, on the basis of the international treaties and the domestic laws of United States, South Korea and China, the matters, not provided in the "Montreal Convention", are applicable to the local domestic law of the locality of the trail court. The victims' families could bring a lawsuit in accordance with the air transport contract in the Contract Law and the infringement of personal right in the Tort Liability 
Law. China, the United States and South Korea have relevant domestic law to adjust this kind of cases. In the Asiana Airline Air Crash, a total of three Chinese students were killed; 28 passengers were injured; all luggage and spirit of all passengers are damaged to different degrees. In this regard, the passengers have the right to claim to Asiana Airline. Chinese passengers who bought a return ticket have the right to bring a lawsuit to the United States courts. The passengers in this accident are willing to choose to raise a claim in the United States, which attracts us to pay close attention to the American Compensation Standard. As is known to all, the scope of compensation for damages, compensation standards varies widely in different countries. American Compensation Standard is much higher than that of China and South Korea, so most of the families of the crash first chose to bring a lawsuit in the United States courts. The courts of the United States adopt the form of jury for this kind of cases. The jury values passengers' psychological and physical damage in the event, so that the amount of compensation is high. Moreover, if the airline company is confirmed with a negligent act, the United States courts may rule the compensation of the airline company higher than the compensation limit stipulated in the international treaties.

\section{Conclusions}

"Montreal Convention” does not make clear provisions on the compensation for mental damage of passengers in air transport. As a federal state, each state of the United States separately legislates. They have no unified national provisions on the compensation for mental damage. America belongs to the list of countries with Anglo American law system, so they may refer to the similar case law and legislation instances during the trial of the Asiana Airline Air Crash case. Through trail, the United States courts may support the request of victims’ families on the compensation for mental damage. Under normal circumstances, if the passengers can provide evidence to prove their body with a certain degree of damage, the Unite States courts would require airlines to give passengers the compensation for mental damage. In other situations, when the courts rule the airline being confirmed with a negligent act, passengers also have the right to acquire compensation for property damage, and other losses besides mental damage. In view of the fact that "Montreal Convention" provisions on the compensation for mental damage are fuzzy, so the victims can sue to the United States courts in order to get the compensation for mental damage. Therefore, it is suggested to perfect provisions of "Montreal Convention" on the compensation for mental damage to facilitate prosecutions and claims of the victims and their close relatives. There are many difficulties during the claim process. The first problem is how long will a claim process last. The experts answer it usually takes three to five years to complete a claim process of an air crash accident. Further, it does not consider the appeal against the verdict. The second is that if the victims and their families choose to reach a settlement with the airline company to obtain compensation, the compensation is usually too low or they cannot sue when they discovery unclaimed rights. Most of the settlement agreement is to ask passengers to give up all future recourse, so it would be best not to sign any commitment document without careful consideration. Otherwise, if passengers may get no compensation once they found sequela in the future. Therefore, it is suggested to perfect the relevant international treaties and domestic laws, and make detailed provisions on the claims process for air crash case and the corresponding rights and obligations. The victims and their families can get compensation as soon as possible, rather than sign a reconciliation agreement hastily due to the cumbersome claim process, nor cannot protect their own legitimate rights and interests of compensation.

Nowadays, the society pays increasing attention to the human rights in China. The fuzziness about the air crash jurisdiction and the over low amount of statutory compensation reveal our unreasonable legislation. For this reason, the author suggests to further perfect the private international law about air crash. Baotou Air Crash and Asiana Air Crash give us an important enlightenment: the rules applicable to the international tort liability of the countries in the world still lack consistency and uniformity. Therefore, it is a long-term arduous task to unify the international rules on international aviation tort liabilities.

\section{References}

[1] Ma, D.C. (2013) Private International Law. Xiamen University Press, Xiamen, 172.

[2] Wang, Y. (2010) Law Evasion on the Compensation for the Foreign Aviation Damages from Baotou Air Crash. Legal System and Society, 7, 65-66.

[3] Qi, X.Q. (2007) Thoughts on Legal Issue of the Nature Transformation of “11.21” Air Crash Case. Chinese Lawyer and Jurist, 3, 19-23. 
[4] Wang, Y.H. (2009) View the Effect of American long Arm Jurisdiction from “11.21” Baotou Air Crash Case. Journal of Jixi University, 4, 48-49.

[5] How Passengers Claim for Compensation in the Air Crash Accident-Answering of Lawyer Zhang Jun in the Supreme Court of the United States. Global, 2013-07-24. 
Scientific Research Publishing (SCIRP) is one of the largest Open Access journal publishers. It is currently publishing more than 200 open access, online, peer-reviewed journals covering a wide range of academic disciplines. SCIRP serves the worldwide academic communities and contributes to the progress and application of science with its publication.

Other selected journals from SCIRP are listed as below. Submit your manuscript to us via either submit@scirp.org or Online Submission Portal.
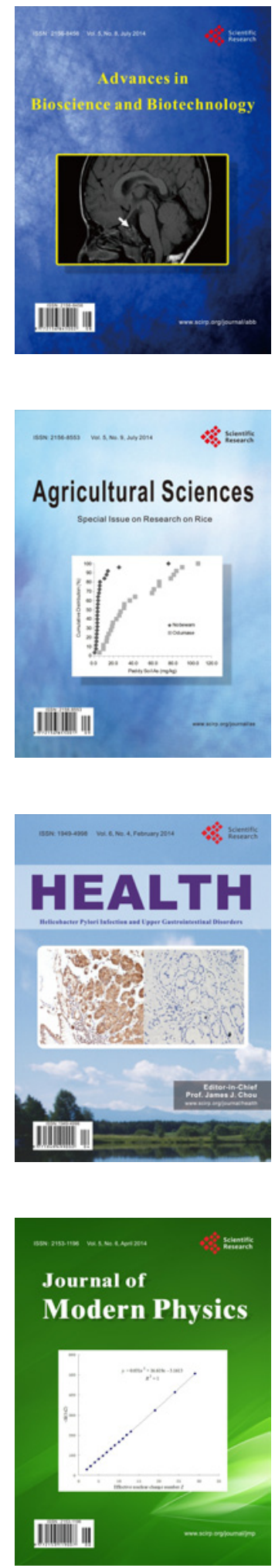
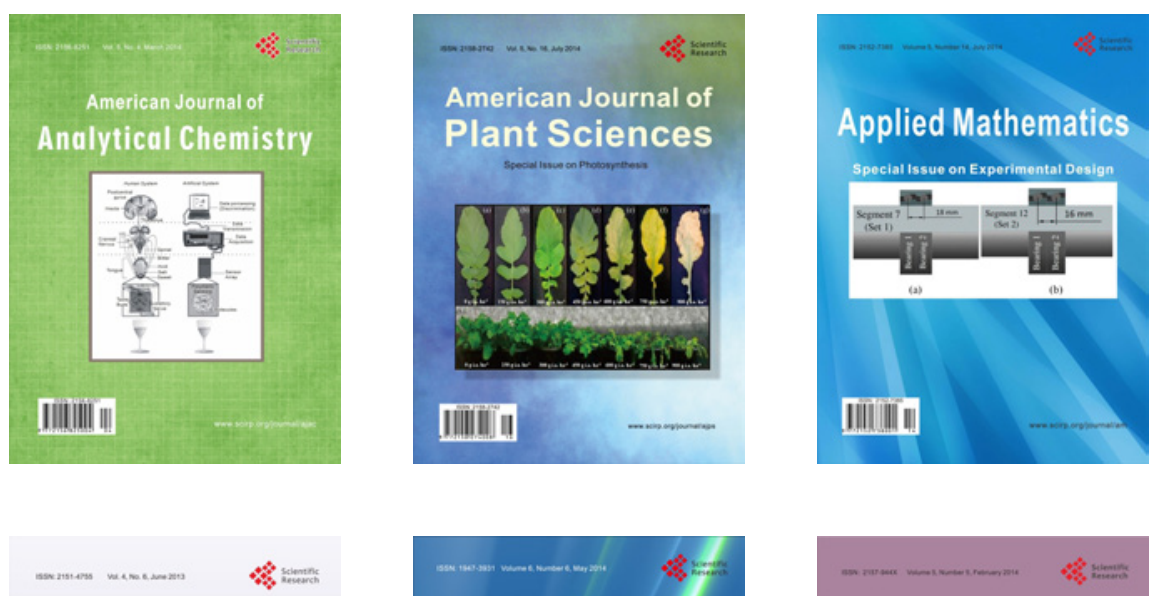

Creative Education
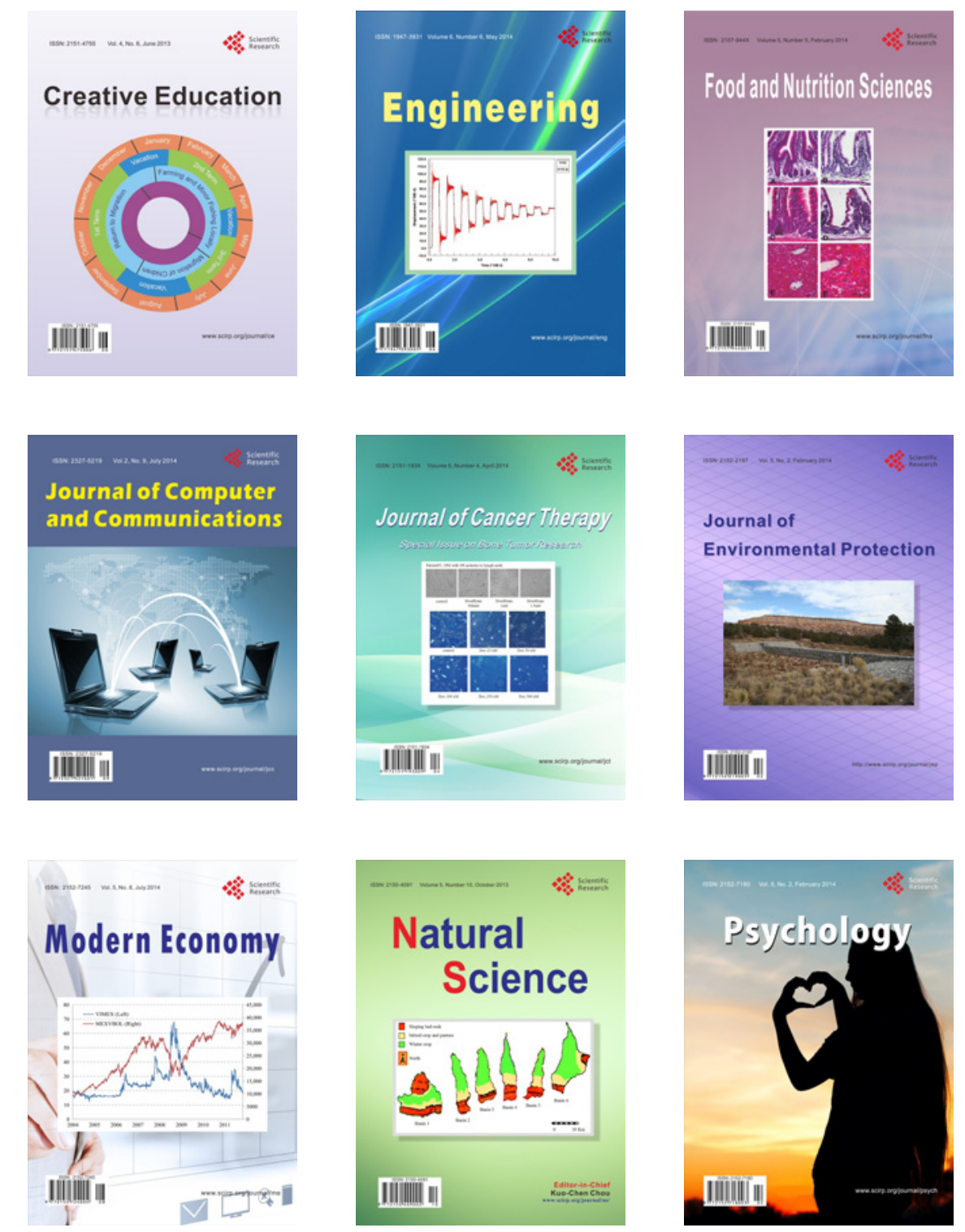